City University of New York (CUNY)

CUNY Academic Works

\title{
MULTI-FACETED GEOSCIENCE RESEARCH USING OPEN ACCESS RESOURCES: THE SUCCESSFUL PARTICIPATION OF K9-16 STUDENTS
}

\author{
Nazrul I. Khandaker \\ cUNY York College \\ Noshin Sharmili \\ Dhaka University \\ Omadevi Singh \\ cUNY York College \\ Gurwinder Sahota \\ CUNY York College \\ Sol De Leon \\ CUNY York College
}

See next page for additional authors

\section{How does access to this work benefit you? Let us know!}

More information about this work at: https://academicworks.cuny.edu/yc_pubs/304

Discover additional works at: https://academicworks.cuny.edu

This work is made publicly available by the City University of New York (CUNY).

Contact: AcademicWorks@cuny.edu 


\section{Authors}

Nazrul I. Khandaker, Noshin Sharmili, Omadevi Singh, Gurwinder Sahota, Sol De Leon, Matthew Khargie, Ali Zarine, Krishna Mahabir, Adacia Teemal, and Mildred M. Selby 


\section{MULTI-FACETED GEOSCIENCE RESEARCH USING OPEN ACCESS RESOURCES: THE SUCCESSFUL PARTICIPATION OF K9-16 STUDENTS}

NASA

KHANDAKER, Nazrul, York College of CUNY, 9420 Guy R Brewer Blvd, AC-2F09, Jamaica, NY 11451-0001, SHARMILI, Noshin, Geology Department, Dhaka University SPE Chapter, Dhaka, NY 1000, Bangladesh, SINGH, Omadevi, NASA MUREP AEROSPACE ACADEMY, York College - City University of New York, 94-20 Guy R. Brewer Blvd., Jamaica, NY 11451, SAHOTA, Gurwinder, Earth and Physical Sciences Department - Geology Discipline, York College-CUNY, 9420 Guy R Brewer Blvd, AC-2F09, Jamaica, NY 11451-0001, DE LEON, Sol, York College NASA MAA Program, Hunter College of CUNY, 695 Park Ave, New York, NY 10065, KHARGIE, Matthew, CoEnterprise, 45 West, 36TH Street, New York City, NY 10018, ZARINE, Ali, Geology Discipline, Earth and Physical Sciences, York College Of CUNY, 94-20, Guy R. Brewer BIvd, Jamaica, NY 11451, MAHABIR, Krishna, Science and Robotics Dept., Grover Cleveland High School, 2127 Himrod Street, Ridgewood, NY 11385, TEEMAL, Adacia, Hillcrest High School, 160-03 Highland Avenue, Queens, NY, NY 11432 and SELBY, Mildred M., NASA MUREP Aerospace Academy, York College-CUNY, 94-20 Guy R. Brewer Blvd, AC-2F09, Jamaica, NY 11451

INTRODUCTION

Students interested in geosciences, for the most part, missed out their traditional field- based research activities due to strict social distancing, travel restrictions and/or lacking financial support.

An absence of physical laboratory opportunities forced underserved students (Image 1) to choose topics deemed doable through online research and python-based programming language. Available data from online sources on extreme weather-related case studies, temperature fluctuations, flooding, droughts, groundwater depletion in urban and suburban areas, coastal erosion rate, sea leve ise, landslides, earthquakes, volcanic eruptions, and Readily availablon bectinent quile handy and lucrative. students to conduct summer research at "stay home" situations (Image 2 through 10).

\section{PEER MENTORING}

Selective peer mentoring was also available remotely to epresentative students, mostly led by geology faculty. It certainly facilitated both individual and group-based learning of geoscience- related research. Group projects were very 作ective in promoting team dynamics by encouraging breakout sessions. This espect is very significant for tudents, considering aspience-related research often equires close collaboration between multiple individuas (Image 11 through 13).

\section{DATA RETREIVAL}

The retrieval of online data mostly became available to tudents from regularly posted information by the NASA Administration, American Meteorological Society, European Space Agency, United States Geological Survey, and Environmental Protection Agency. Filtering of critical data and establishing their relevance to a chosen topic often required patience and proper time management.
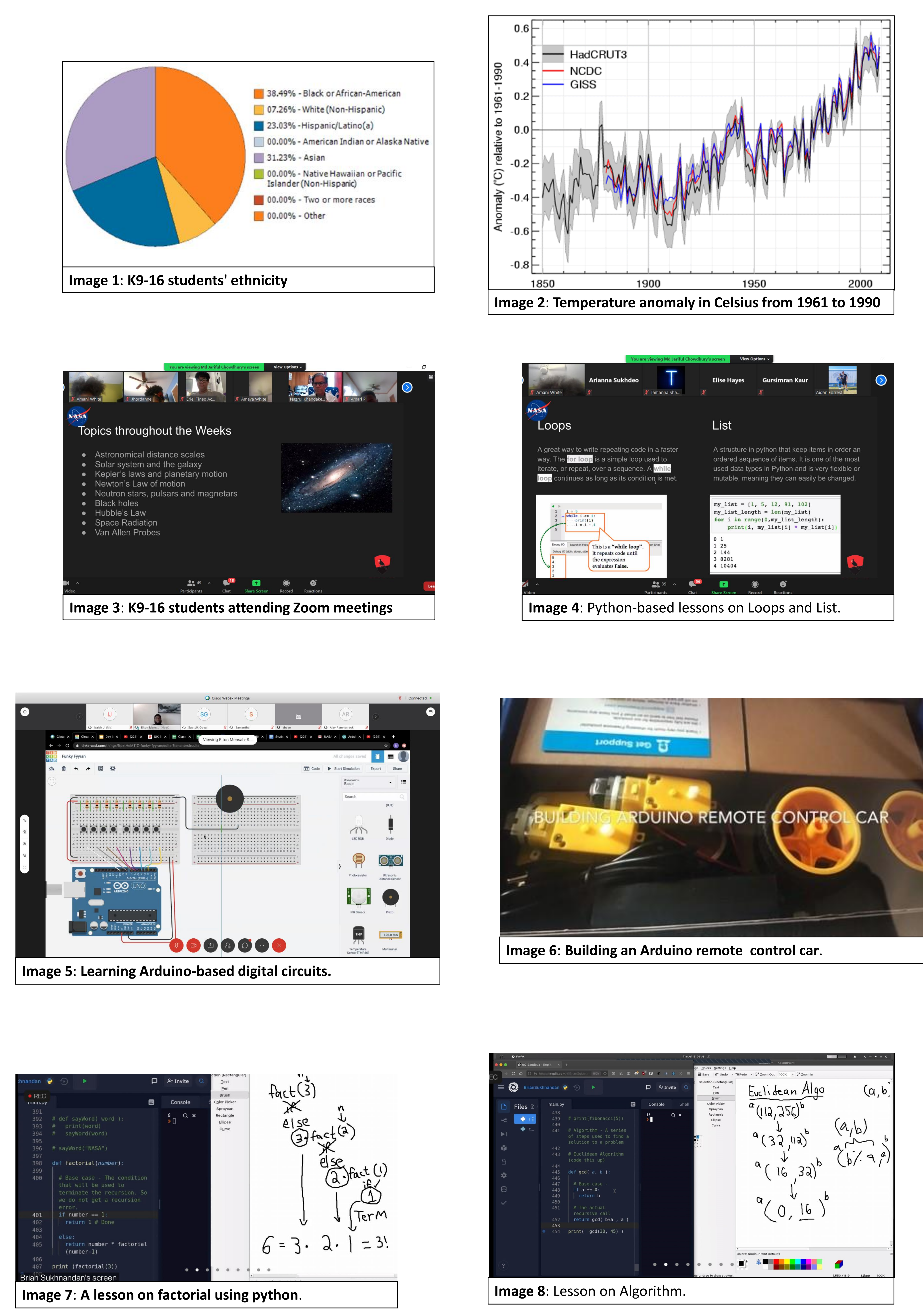

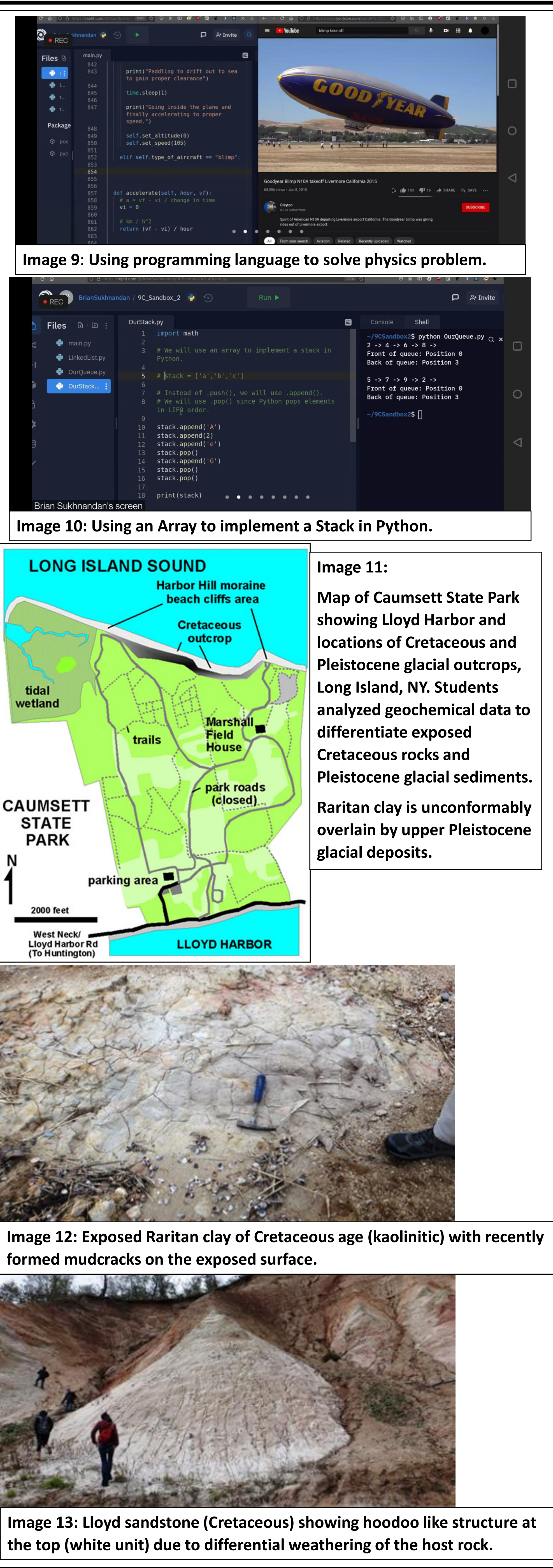

DATA ANALYSIS

Once the data were selected, students needed to run basic statistical investigations and produce graphical bearing on the overarching research question.

\section{SUMMARY}

The outcome is that COVID 19 opened up a new dimension and pedagogical approach to engage K9-16 students in geoscience-related and python-based research investigation.

Engaged students became proficient in data collection echniques, acquired scientific communication skills, and arnt about time management.

Overall, the K9-16 students involved became selfmighly successful in reaching their research goals.

\section{ACKNOWLEDGEMENTS}

The authors greatly acknowledge the research opportunity provided by The Cly University of New York (CUNY) York College-hosted NASA MAAMUREP (Mhority) University Research and Education Project Aerospace emy) 2021 Program.

Funding from AT\&T and ConEdison helped to support students receiving peer mentoring and research experience during the global COVID-19 pandemic.

ABSTRACT

Geological Society

doi: 10.1130/abs/2021AM-367040 